\title{
Türkiye'deki Evli Bireylerin Sosyal Medya Kullanımlarının Evlilikleri Üzerine Etkisi: Nitel Bir Araştırma
}

\author{
DOI: 10.26466/opus.589684
}

\author{
Sefer Kalaman*- Fatih Çelik** \\ * Dr. Öğr. Üyesi, Bozok Üniversitesi, İletişim Fakültesi, Yozgat / Türkiye \\ E-Posta: sefer.kalaman@bozok.edu.tr \\ ORCID: 0000-0002-2761-1229 \\ ** Dr. Öğr. Gör., Trabzon Üniversitesi, Vakfıkebir MYO, Vakfıkebir /Trabzon / Türkiye \\ E-Posta: fatihcelik@trabzon.edu.tr \\ ORCID: 0000-0002-3765-5284
}

\section{Öz}

Araştırmada, Türkiye'deki evli bireylerin evliliklerinde ya da evlenme süreçlerinde sosyal medyanın rolünün olup olmadığını ve evliliklerinde sosyal medyanın aile iç problemlere yol açıp açmadığını ortaya çıkarmak amaçlanmaktadır. Araştırma verilerini elde etmek için nitel araştırma yöntemlerinden biri olan yarı yapılandırılmış görüşme tekniği kullanılmıştır. Görüşme, Mart 2019 - Nisan 2019 tarihleri arasında $X$ ve $Y$ kuşă̆ında bulunan, sosyal paylaşım ağı kullanan ve Türkiye'nin farklı illerinde yaşayan evli bireylerle gerçekleştirilmiştir. Araştırmanın evrenini, Türkiye'de yaşayan evli bireyler oluşturmakta iken, Türkiye'nin farklı illerinde ikamet eden 60 evli birey ise, örneklem olarak seçilmiştir. Çalışmada elde edilen bulgulara göre sosyal medya hem evlenmeden önceki süreçte hem de evlendikten sonraki süreçte bireylerin hayatında aile içi ilişkiler noktasında önemli bir rol oynamaktadır. Bununla birlikte, evli bireylerin aile içi ilişkilerinde sorunların oluşmasında velveya evliliklerini sonlandırmalarında sosyal medya önemli bir neden olabilmektedir. Çalışmada ayrıca evli bireylerin bulunduğu kuşaklarla ve demografik özellikleriyle, aile içi ilişkileri ve sosyal medyanın bu süreçteki yeri karşılaştırılmış ve anlamlı farklılıklara ulaşılmıştır.

Anahtar Kelimeler: Türkiye, Sosyal Medya, Evlilik 


\title{
The Impact of The Usage of Turkey's Married Individuals' Social Media Usage on Their Marriage: A Qualitative Research
}

\begin{abstract}
In the study, it is aimed to reveal that whether the role of social media in the marriage and the marriage process exists or whether social media in the marriage causes internal family problems. Semi-structured interview technique, one of the qualitative research methods, was used to obtain the research data. Interview was carried out with the $X$ and $Y$ generations, using social networking and married individuals living in different provinces of Turkey from March 2019 to April 2019. While the universe of the study consists of married individuals in Turkey, 60 married individuals residing in different provinces were selected as samples. According to the findings obtained in the study, social media has an important role in the life of individuals both before and after marriage in terms of family relations. However, social media can be an important reason for married individuals to have problems in their family relationships and/or to terminate their marriage. The study also compared the generations of married individuals and their demographic characteristics, family relations and the place of social media in this process and remarkable differences were reached
\end{abstract}

Keywords Turkey, Social Media, Marriage 


\section{Giriş}

İnsanoğlu var olduğu andan itibaren hayatta kalmak, topluluk oluşturmak, iş paylaşımı yapmak ve aile kurmak gibi amaçlar doğrultusunda birbirleri ile iletişim kurmaktadırlar. Söz konusu iletişim, önceleri yüz yüze iletişim yöntemi ile gerçekleşmiş, ardından da resim, ateş, yazı ve kitle iletişim araçları gibi unsurlarla boyut değiştirmiştir. İletişimin çeşitlenmesine ve evrilmesine önayak olan bu gelişmeler özelde bireyin, genelde ise toplumun farklı açılardan dönüşmesine neden olmuştur. Yeme-içme alışkanlıkları, sosyalleşme süreçleri, alış-veriş pratikleri, çalışma hayatı, eğitim, aile içi ilişkiler ve daha birçok hayat alanı/pratiği başta kitle iletişim araçları olmak üzere bu iletişim alanındaki gelişmeler paralelinde değiş̧miştir.

Bu bağlamda, endüstri devrimi ve teknolojinin gelişimini, bunun sonucu olarak göçlerle oluşan kentleşme süreci ve matbaanın icadıyla başlayıp gelişen kitle iletişim araçlarını, insanların toplumsal ilişki kurma biçimlerini ve dolayısıyla iletişim süreçlerini etkileyen belli başlı faktörler olarak düşünmek gerekmektedir. Söz konusu teknolojik gelişmeler paralelinde aynı siyasal, toplumsal ve ekonomik süreçleri yaşayan bu insan toplulukları belli yıllar baz alınarak kuşak olarak adlandırılmıştır (Okur ve Özkul, 2015, s.216; Kılıç ve Gündoğdu, 2017, s.20).

Yıllar içerisinde paylaşılan ortak koşullar, yaşanılan deneyimler, kuşakların birbirinden farklı özellikler taşımasına neden olmuştur. Her kuşağın sahip olduğu farklı deneyimler, yaşam biçimleri, değerleri ve inançları onları birbirinden ayırmıştır (Baycan, 2017, s.2). Tarih noktasında kuşak sınıflandırmasına bakıldığında; “Sessiz Kuşak (Gelenekselciler), Baby Boomers (Bebek Patlaması), X Kuşağı, Y Kuşağ1 ve Z kuşağı” olarak genel bir sınıflandırma yapılabilir. 1925-1945 yılları arasında dünyaya gelenlerin oluşturduğu kuşağa 'Sessiz Kuşak' denilmektedir ki bu kuşak büyük buhranı ve II. Dünya Savaşı'nı görmüştür. Diğer taraftan, 1946-1964 tarihleri arasında doğan kuşağa ise, 'Baby Boomers' kuşağı denilmektedir. Bu kuşak ise savaşta azalan nüfusun yerine ikame etmek için toplumda doğum oranlarının arttığı bir döneme işaret etmektedir. Bir diğer kuşak olan 'X kuşağı', 1965-1979 yılları arasında doğanları kapsamaktadır (Acılıoğlu, 2015). Bunun yanı sıra, 'Y kuşağı'nın hangi yılları net olarak kapsadığı noktasında görüş farklılıkları olsa da çalışma kapsamında bu kuşağın 
1980-2000 yılları arasında doğan kuşağı kapsadığı kabul edilmektedir. Y Kuşağı aynı zamanda "internet kuşağı, echo-boomers, millenial ve nexters" olarak da anılmaktadır (Broadbridge vd., 2007, s.8). Son olarak, internetin yaygınlaştığı dönem olan 2000'li yılların ilk çeyreğinde doğan kuşak ise literatürde ' $Z$ kuşağı' olarak adlandırılmaktadır. Teknolojinin ve internetin 'öz evlatları' olan bu kuşak aynı zamanda, "internet kuşağı, next generation ya da dijital yerliler" olarak da adlandırılmaktadır (Prensky, 2001).

Toplumların şekillenmesi, kuşakların oluşması ve insan hayatına etki etmesi noktasında ele alındığında iletişim alanındaki bu gelişmelerin belki de en önemlisi ve en etkilisi internettir. İnternet ve özelikle internetin en çok kullanılan ortamı olan sosyal medya, toplumu ve toplumun çekirdeği olarak adlandırılan aileyi önemli şekilde etkilemiştir. Gerek toplumda gerekse de aile içinde gerçekleştirilen yüz yüze ve çevrimdışı iletişim gittikçe yerini sanal ortamda gerçekleştirilen çevrimiçi iletişime bırakmaya başlamıştır.

Gelinen son noktada, toplumun tüm alanlarında sosyal medya kullanımı ciddi oranda yaygınlaşmıştır. İnsanların büyük çoğunluğu bilgisayarı açar açmaz ya da akıllı telefonları ellerine alır almaz öncelikle sosyal medya sayfalarına bakmakta ve farkına varmaksızın bu sayfalarda ihtiyacı olandan daha fazla zaman harcamaktadır. Aile içerisinde anne-baba ve çocuklarda bu durum ciddi bir iletişim kopukluğuna yol açmaktadır. Bakıldığında, özellikle toplumda aile üyeleri, iletişim biçiminin en açı ve sağlıklısı olan yüz yüze iletişimden daha çok çağımızın popüler iletişim ortamı olan sosyal medyada vakit geçirmektedir. Bu durumun, insanları zamanla sosyal medya sayfalarına bağımlı bireyler haline getirmesi kaçınılmazdır (Güleç, 2018, s.106).

Bireyler sosyal medyadaki sanallık içerisinde kendilerine gerçekmiş gibi yaşanılan bir çevre yaratmakta ve bu çevre onlar için ikinci bir yuva haline gelmektedir. İnternetteki paralel dünya, günlük hayattaki ikinci bir gerçeklik haline dönüşmüştür. Gerçek yaşamdaki ilişkiler bütünü - aile, arkadaşlar, tanıdıklar, iş arkadaşları, amirler, komşular vs. - sosyal medya aracılığıyla sanal gerçekliğe aktarılmaktadır. İletişimin sanallaşması ve gerçek temassal iletişimin önüne geçmeye başlaması blog, Facebook, Twitter, WhatsApp vb. sosyal medya ağları aracılığıyla oluşmuştur (Uslu, 
2012, s.64). Öyle ki, bireyler sosyal ağlarda kendilerine arzu ettikleri biçim ve çeşitlilikte kimlikler dâhi oluşturabilmektedir (Güz ve Yegen, 2017).

Sağlıklı bir toplumun temel gereksinimi olan doğru iletişimin yolu, toplumun çekirdeği olarak kabul edilen ailedeki iletişimin sağlıklı olmasından geçmektedir (Güleç, 2018: 106). Ancak bakıldığında günümüzde bireyler artık kamusal ya da özel ilişkilerini dijital ortamda sürdürmeyi daha fazla tercih etmektedir. Özellikle çiftlerin romantik ilişkileri bağlamında değerlendirildiğinde, çiftlerin ilişkilerini yaşarken sosyal medya kullanımında birbirlerinin şifrelerini öğrenme isteği, arkadaş listelerini kontrol etme gibi yeni davranış kalıpları geliştirdikleri görülmeye başlanmıştır. Bu durum da sosyal medya kullanımının çiftlerin ilişkilerinde ne denli etkili olduğunu göstermektedir (Alikılıç vd., 2019, s.59). Dolayısıyla sosyal medya, evliliklerin her aşamasında çiftler arasındaki ilişki ve iletişimi etkileyen, yön veren ve evlilikte bazı işlevleri olan önemli bir faktör haline gelmiştir (Can ve Hovardaoğlu, 2015, s.45).

Öyle ki, çağın etkili toplumsal paradigmaları olarak modernite ve postmodernite, teknoloji üzerinden birey ve toplum hayatına girmektedir. Teknoloji özelinde ise, özellikle internet ve buna bağlı olarak sosyal medyanın çoğunlukla genç kuşaklar üzerinde etkili olduğu ve onlara yeni değer, tutum, bilgi ve beceriler telkin ettiği görülmektedir (Özpolat, 2014, s.46). Marshall vd. (2013) de belirttiği gibi artık bireyler, sosyal medya aracılığıyla her zamankinden daha fazla etkileşim içerisine girmekte, bu ağda romantik ilişkiler kurmakta, özel iletişim oluşturmakta, gruplara katılmakta, ilişkisi olduğu ya da olmasını istediği kişiyi izlemekte, kıskanma ve daha birçok kişisel aktiviteleri ve duyguları bu sanal ağlar üzerinden yaşayarak sürdürmektedir. Tokunaga (2011) ile Fox ve Warber (2014) de sosyal medya üzerine yaptığı çalı̧̧malarda, evli ya da bekar çiftlerin sosyal medya aracılığıyla birbirlerini gözetlediklerini, bu ağ sayesinde iletişim kurduklarını ve ilişkilerini sürdürdüklerini ifade etmektedirler.

Sosyal medyanın aile içi etkileşimi en çok etkilediği boyutlar incelendiğinde ise, birinci olarak aile üyelerinin birlikte geçirdikleri zaman dilimlerinin yerini sosyal medyada geçirilen sürenin alması iken, ikinci olarak sanal alemin verdiği esneklik ve bilinmezliğin etkisiyle sanal flörtlerin ve sanal aldatmaların yaşanmasına zemin hazırlamasından dolayı eşler arasinda güvensizlik ve huzursuzluk oluşturması gösterilebilmektedir (Gü- 
leç, 2018, s.106). Öyle ki evli bireylerin boşanmaları normal koşullarda, bireyselleşmenin artması, evlilik dişı ilişkilerin özendirilmesi, cinsel hayattaki sorunlar, aile içi şiddet, aldatma, içinde bulunulan hayattan/evden/aileden tatmin olunmama, maddi sorunlar, geçimsizlik gibi nedenlerle gerçekleşebilmektedir. Ancak bunun yanında 21. yüzyılda evli çiftlerin huzursuzluk yaşamalarına ve boşanmalarına neden olan ya da aracı olan diğer önemli unsur da sosyal medyadır.

Aile kurumunda yaşanan değişmelerde ve boşanma oranlarının artmasında sosyal medya olarak adlandırılan kitle iletişim aracının etkisi yadsınamaz derecede büyüktür. Bu kanallar vasıtasıyla flört ilişkiler bir yandan insanlara normal bir yaşam tarzıymış gibi empoze edilirken, aynı zamanda da aile içindeki kopukluklar ve bunun akabinde gelen boşanmalar hayatın akışı içinde olağan bir durum gibi bahsedilmektedir (Subaşı ve Urtekin, 2014, s.610).

Bakıldığında günümüzde aile ilişkileri, 'pamuk ipliğine' bağlı hale gelmiştir. Televizyonla birlikte zedelenen aile içi iletişim internet ve sosyal medya sebebiyle kopma noktasına ulaşmıştır. Anne, baba ve çocuklar; sosyal ağlarda paylaşımda bulunmayı eşiyle ya da çocuğuyla geçireceği zamana tercih etmekte ve yanlış kişilerle, yanlış ilişkiler kurmaktadır. Bu durum da aile bütünlügünün bozulmasına ve boşanmaların hızla artmasina sebebiyet vermektedir (Uluslararası Hak İhlalleri İzleme Merkezi [UHIM], 2011, s.16). Çünkü, dört duvar arasında yaşanması gereken evlilik kurumunun artık ekran karşısındaki herkes tarafından izlenebilir olması ya da sosyal medyada insanların gözetimine açılması, evlilik kurumunun zarar görmesine ve içinin boşaltılmasına neden olmaktadır. Bireyler bu nedenle değersizleştirilmiş evlilik kurumuna daha az önem vermekte ve yaşadıkları boşluğu yine sosyal medya aracılığıyla doldurmaya çalışmaktadır. Bu durum bireyi var olduğu durumdan daha yalnız hale getirmekte; başka bir deyişle onu yabancılaştırmakta ve yalnızlaştırmaktadır. Öyle ki bu yalnızlık duygusu sadece gençlerde değil 30 yaşın üstündeki evlenmemiş kişilerde de görülmektedir (Yıldız, 2012, s.532). Yalnızlık duygusunu gidermek isteyen birey sosyal medya kullanımının haricinde dijital oyunlar vasıtasıyla da ilişki kurabilmekte hatta bu sanal oyunlarda evlilik yapabilmektedir.

Bu dijital oyunlarda evlenen çiftler kendi istekleri ile ayrılıncaya kadar evli kalmakta ve yapılan sanal evlilikler aylarca sürebilmektedir. Sanal, 
kurgusal evren artık evlilik kültürüne kadar uzanmıştır. Bu durum gerçek yaşamda birçok maddi ve manevi külfetle yapılabilen evlilikleri sanal ortamda çok basite indirgemiştir. Sanal evliliklerin yapılabilir hale gelmesi evlilik kültürüne bakışı dönüştürmektedir. Görücü usulü ile yapılan evlilikler artık sosyal medya oyunlarına taşınmıştır. Oyunda birbirlerini görmeden tanışan oyun kullanıcıları birbirlerini çift uyumu gibi yarışmalar ile taniyarak sanal ortamda evlenmektedirler (Uslu, 2012, s.78).

Sanal ortamda gerçekleştirilen bu faaliyetler hem toplum yapısına hem aileye hem de bireylere belki de dönüşü mümkün olmayacak zararlar vermektedir. Maddi varlık nasıl her geçen gün daha fazla sanallaşıyorsa/dijitalleşiyorsa aynı şekilde manevi hazlar ve değerler de git gide daha fazla sanal ortama uyum sağlamaktadır. Bu noktadan yola çıkarak yapılan söz konusu bu çalışmada, Türkiye'deki evli bireylerin sosyal medya ile olan ilişkileri ve bu ilişkiler dâhilinde evliliğin sosyal medya aracılığıyla nasıl dönüştüğü ve zarara uğratıldığı ele alınmaktadır.

\section{Yöntem}

Araştırmada, Türkiye'deki evli bireylerin evliliklerinde sosyal medyanın ne düzeyde etkili olduğunu ortaya çıkarmak amaçlanmaktadır. Çağın değişmesi paralelinde iletişim, teknoloji ve aile içi ilişkiler farklı boyutlara evrilmiştir. Hiç kuşkusuz ailenin oluşma aşamasında veya aile içi problemlerin ortaya çıkmasında sosyal medya önemli bir unsur haline gelmiştir. Birçok akademik çalışmada ise, aile içi ilişkilerin şekillenmesi, tartışmaların yaşanması hatta boşanmaların meydana gelmesinde sosyal medyanın önemli bir payının bulunduğu ortaya konulmaktadır. Bu noktadan hareketle, Türkiye'deki evli bireylerin sosyal medya kullanımlarının onların evlilikleri üzerinde nasıl bir etki bıraktığının/nasıl bir rol oynadığının analiz edilmesi ve aile içi problemlerde sosyal medyanın ne denli etkisinin olduğunun ortaya çıkarılması önemli olmaktadır. Türkiye'de aile içi şiddet ve boşanma davaları ile ilgili çalışmalar mevcut olmaktadır. Ancak sosyal medya ve evliliğin inşa edilmesi, aile içi şiddet, boşanma arasındaki ilişki çok az irdelenmiştir. Bu nedenle çalışmanın evlilik ile sosyal medya arasındaki ilişkiyi derinlemesine inceleyecek olması nedeniyle literatüre katkı sağlayacağı düşünülmektedir. 
Araştırmada verileri elde etmek için nitel araştırma yöntemlerinden biri olan yarı yapılandırılmış görüşme tekniği kullanılmıştır. Görüşme, x ve y kuşağında bulunan, sosyal paylaşım ağı kullanan ve Türkiye'nin farklı illerinde yaşayan evli bireylerle gerçekleştirilmiştir. Görüşmede, katılımcılara açık uçlu sorular yöneltilmiş ve bu sayede katılımcıların konu ile ilgili daha detaylı bilgi vermeleri istenmiştir. Araştırmanın evrenini Türkiye'deki evli bireyler oluşturmaktadır. Araştırmanın örneklemini ise, Türkiye'nin farklı illerinde ikamet eden 60 evli birey (30 çift) oluşturmaktadir.

\section{Veri Toplanma Araçları ve Analiz}

Türkiye'deki evliliklerde sosyal medyanın ne düzeyde etkili olduğunu tespit etmek için yapılan görüşmeler Mart 2019-Nisan 2019 tarihleri arasında gerçekleştirilmiştir. Veriler elde edilirken görüşmede katılımcılara 22 soru yöneltilmiştir ancak bazı sorular kendi içerisinde 3 veya 4 soru barındırmıştır. Katılımcılara sorulan sorular ve alınan cevaplar kapsamında elde edilen veriler kayıt altına alınmış ve analize hazır hale getirilmiştir. Verilerin analizinde MAXQDA adlı nitel analiz programı kullanılmıştır.

\section{Analiz ve Bulgular}

Araştırmada, görüşmelerden elde edilen veriler üç temel bölüme ayrılarak incelenmiştir. Bu bölümler; katılımcıların demografik özellikleri, katılımcların sosyal medya kullanım pratikleri ve evli çiftlerin sosyal medya kullanımlarıdır. Üç bölümden ve toplam 22 sorudan oluşan görüşme formu katılımcılara yöneltilmiş ve katılımcılardan elde edilen cevaplar sistematik olarak toplanmıştır. Bu bölümler için toplamda 174 koda ulaşılmıştır. Bu minvalde, verilen cevaplarda 1068'i kadın ve 1052'si erkek olmak üzere toplam 2120 ifadenin kodlaması yapılmıştır (Tablo 1).

Tablo 1. Belge-Kod Dağılımı

\begin{tabular}{lll}
\hline & Kategoriler & Sayı \\
\hline Belgeler & Kadın & 1068 \\
& Erkek & 1052 \\
\hline Etkin Kod & & 174 \\
\hline
\end{tabular}




\section{Katılımcıların Demografik Özellikleri}

Çalışmada yer alan katılımcıların 30'u erkek ve 30'u da kadındır. Katılımcıların çoğunluğu 20-40 yaş arasında başka bir deyişle Y kuşağında, farklı eğitim seviyelerine sahip ve çoğunluğu çalışmaktadır. Ayrıca katılımcların yarısına yakının aylık geliri 4000 TL'nin altında ve diğer yarısının aylık geliri de 4000 TL'nin üstündedir. Son olarak, katılımcıların büyük çoğunluğu en fazla 10 yıldır evli ve çocuk sahibidirler (Tablo 2).

Tablo 2. Katılımcıların Demografik Özellikleri

\begin{tabular}{lll}
\hline & Kategoriler & Sayı \\
\hline Cinsiyet & Kadın (K1-K30) & 30 \\
& Erkek (E1-E30) & 30 \\
\hline Yaş & $20-40$ & 46 \\
& 41 ve üstü & 14 \\
\hline Eğitim Durumu & İlköğretim/Ortaöğretim & 14 \\
& Lise & 11 \\
& Ön Lisans & 7 \\
& Lisans & 22 \\
& Lisansüstü & 6 \\
\hline Çalışma Durumu & Çalışıor & 37 \\
& Çalışmıyor & 23 \\
\hline Ailenin Aylık Toplam & $0-2000$ TL & 18 \\
Geliri & $2000-4000$ TL & 10 \\
& $4001-6000$ TL & 17 \\
& 6001 TL-ve üstü & 15 \\
\hline Evlilik Yılı & $0-5$ Yil & 28 \\
& $6-10$ Yıl & 12 \\
& $11-15$ Yil & 6 \\
& $16-20$ Yıl & 4 \\
& 21 Yıl-ve üstü & 10 \\
\hline Çocuk & Var & 40 \\
& Yok & 20 \\
\hline
\end{tabular}

\section{Katılımcıların Sosyal Medya Kullanım Pratikleri}

Araştırmaya dahil olan katılımcıların sosyal medya kullanım alışkanlıkları incelendiğinde, katılımcıların çoğunluğunun interneti günde en az 3 saat kullandıkları ve interneti en fazla sosyal medyaya girmek için tercih ettikleri görülmektedir. Bakıldığında Türkiye İstatistik Kurumu 
(TÜİK)'nun 2018 verilerine göre, Türkiye' de internet erişimi olan bireylerin \%84,1'i sosyal medyaya girmek için internet kullanmaktadırlar (TÜiK, 2018). Bunun yanı sıra, katılımcıların büyük çoğunluğunun en fazla 3 tane sosyal paylaşım ağına sahip olduğu, yine büyük çoğunluğunun sosyal medyaya günde en fazla 3 saat girdiği ve bu sanal ortamı en fazla iletişim kurmak için kullandıkları görülmektedir (Tablo 3).

Tablo 3: Sosyal Medya Kullanım Pratikleri

\begin{tabular}{lll}
\hline & Kategoriler & Sayı \\
Günlük Ortalama İnternet Kullanım Süresi & 0-2 Saat & 26 \\
& 3-4 Saat & 12 \\
& 5-6 Saat & 10 \\
& 7 Saat ve üzeri & 12 \\
\hline İnternet Kullanım Amacı & Sosyal Medya & 13 \\
& Araştırma Yapma & 11 \\
& Haber ve Bilgi & 9 \\
& İletişim Kurma & 9 \\
& Eğlence & 6 \\
& Oyun Oynama & 5 \\
& Eğitim & 3 \\
& Film İzleme & 2 \\
& Meslek & 1 \\
\hline Toplam Sosyal Paylaşım Ağı Sayısı & 1-3 & 50 \\
& 4-6 & 10 \\
\hline Günlük Ortalama Sosyal Medya Kullanım Süresi & $0-2$ Saat & 39 \\
& 3-4 Saat & 9 \\
& 5-6 Saat & 12 \\
& 7 Saat ve üzeri & 2 \\
\hline Sosyal Medya Kullanım Amacı & İletişim Kurma & 21 \\
& Haber ve Bilgi & 16 \\
& Eğlence & 15 \\
& Araştırma Yapma & 3 \\
& Eğitim & 2 \\
& Alişveriş & 1 \\
& Merak & 1 \\
& Meslek & 1 \\
\hline & &
\end{tabular}

\section{Evli Çiftlerin Sosyal Medya Kullanımı}

Araştırmanın temel amacı olan, evli çiftlerin sosyal medya kullanım alışkanlıkları ve evlilik-sosyal medya ilişkisi değerlendirmeleri aşağıda alt 
başlıklar halinde ele alınmıştır. Bu bölümde toplamda 10 kategori ve 105 kod araştırmaya dahil edilmiştir.

\section{İlişki Durumunun Yazılması}

Evli çiftlerin sosyal medya hesaplarında ilişki durumlarını yazıp yazmadığı incelendiğinde, $21^{\prime} i$ kadın ve 23 'ü erkek olmak üzere toplam 44 katılımcının evli olduklarını sosyal medya hesabında belirtikleri, 9'u kadın ve 7 'si erkek olmak üzere toplam 16 katılımcının ise, belirtmedikleri tespit edilmiştir. Bu durumda, erkeklerin kadınlara oranla sosyal medyada ilişki durumlarını, küçük bir farkla olsa da daha çok yazdıklarını söylemek mümkündür. Evli çiftlerin ilişki durumlarını sosyal medyada en çok yazma sebebi ise, evli olduğunu diğer kullanıcılara belirtme isteğidir. Diğer bir neden, başka kullanıcılar tarafından rahatsız edilmek istememe düşüncesidir. İlişki durumunu sosyal paylaşım ağındaki profilde belirtme nedeninin biri de profil oluşturulurken ilişki durumu kısmının doldurulma teklifinin geri çevrilmemesidir. Sosyal paylaşım ağlarında rahatsız edilmeme düşüncesi noktasında, 6 yıldır evli olan ve sosyal medyayı daha çok arkadaşları ile iletişim kurmak için kullanan bir kadın katılımcı şu ifadeleri kullanmıştır:

"Sosyal medya hesabımda ilişki durumu evli yazıyor. Neysem o. Gizleyecek bir şeyim yok. Daha önce yazmıyordu aslında. Sonra birkaç kişi beni rahatsız etti ve bundan dolayı yazmak zorunda kaldım. Yazdiktan sonra kimse bir daha rahatsiz etmedi". (K28)

Y kuşağında yer alan kadın katılımcı daha önce sosyal medyada ilişki durumunda evli yazmadığı için birkaç kişi tarafından rahatsız edildiğini söylemektedir. Sosyal medyada insanların karşı cins ile iletişim kurmada günlük hayata göre daha rahat davrandıklarını söylemek mümkündür. İnsanlar; "eğer bir olumsuzluk olursa günlük hayatta bu kişiyle karşılaşmam" düşüncesiyle sosyal medyada diğer kullanıcılarla iletişim kurmaya çalışmaktadırlar. Katılımcı rahatsız edici bu durumundan sonra profilinde evli olduğunu yazmıştır ve ondan sonra hiçbir kullanıcı tarafından artık rahatsız edilmemiştir.

Katılımcıların ilişki durumlarını sosyal medyada yazmamalarının en temel sebebi ise, böyle bir şeye gerek duymamalarıdır. Bununla ilgili katı- 
lımcılar 15 defa bildirimde bulunmuştur. Ayrıca 1 kez de sahte hesap kullanıldığı için ilişki durumunun sosyal medya hesabında yazılmadığı belirtilmiştir.

\section{Aile ile İlgili Paylaşım Yapma}

Evli çiftlerin sosyal medya hesaplarında aile ile ilgili paylaşım yapıp yapmadıklarına bakıldığında, 17 'si kadın ve 17 'si erkek olmak üzere toplam 34 katılımcının aileleri ile ilgili sosyal medyada paylaşım yaptığı, 13'ü kadın ve 13'ü erkek olmak üzere toplam 26 katılımcının ise herhangi bir aile paylaşımı yapmadıkları görülmüştür. Bu noktada, cinsiyetler arası bir farklılaşma söz konusu değildir.

Evli çiftlerin aile ile ilgili sosyal medyada en çok paylaşım yapma sebebi, paylaşımlarını diğer kullanıcılara gösterme isteğidir. Diğer bir neden ise, aile paylaşımları yapmaktan hoşlanmadır. Aynı zamanda aile mutluluğunu paylaşma isteği bir diğer aile ile ilgili paylaşım yapma gerekçesidir. Bunun yanında katılımcıların sosyal medyada aile ile ilgili paylaşım yapmamalarının en temel sebebi ise, mahremiyet ve özel hayatın gizliliğidir. Katılımcıların sosyal paylaşım ağlarında aile ile ilgili paylaşım yapmamalarının diğer nedeni ise bu durumun doğru bir davranış olmamasıdır. Diğer bir neden de gösterişten kaçınma isteğidir. Bu konuda, özel hayatın gizliliği ve mahremiyetin önemi ilgili, 21 yıl ve üzeri süredir evli olan ve sosyal medyayı daha çok arkadaşları ile iletişim kurmak için kullanan bir erkek katılımcı şu ifadeleri kullanmıştır:

"Benim özel hayatım olduğu için ailem ve özellikle de eşim ile ilgili paylaşımlar yapmiyorum. Neden benim özelimi diğer insanlar görsün ki? Ailem ile ilgili çekindiğimiz fotoğrafları veya videoları kimse ile paylaşmadan saklıyorum. Hatta ara ara açıp tekrar bakıyorum. Ama dediğim gibi bunları aile dışından kimse ile paylaşmıyorum. Her ne kadar sosyal medya bunu aşındırsa da özel hayatın mahremiyeti diye bir şey var". (E1)

Bir diğer örnekte ise, 10 yıldır evli olan, lisansüstü eğitim düzeyine sahip ve sosyal medyayı daha çok haber ve bilgi için kullanan, çocuk sahibi bir erkek katılımcı ise şu ifadeleri kullanmıştır:

"Çocuklar ile ilgili paylaşım yapıyorum. Fakat eşimin yer aldı̆̆̆ içerikleri paylaşmıyorum. Bu tamamen eşim ile alakah bir durum. Eşim bunu dindar olduğu için istemiyor. Benim arkadaş listemdeki erkekler için, "neden beni görsünler ki?" 
diye düşünüyor. Bu yüzden eşimin olduğu içerikleri sosyal medyada paylaşmıyorum". (E29)

\section{Sosyal Medyadan Tanışma ve Görüşme ile Sosyal Medyayı Evliliklerin Başlangıcı için Güvenilir Bulma}

Araştırmaya katılan evli çiftlerden 14 kişi sosyal medya üzerinden tanıştıklarını söylerken, 46 kişi sosyal medya üzerinden tanışmadıklarını belirtmektedir. Ayrıca 18 katılımcı tanıştıktan sonra sosyal medyadan görüştüklerini söylerken, 42 kişi ise, tanıştıktan sonra sosyal medya üzerinden görüşmediklerini söylemektedir. Buna göre, katılımcıların birçoğu çevrimdışı ortamda tanışmış ve birbirileriyle yüz yüze görüşmeyi tercih etmiştir. Ayrıca 4 katılımcı her ne kadar sosyal medyada tanışmasalar da tanıştıktan sonraki görüşme sürecinin sosyal medya üzerinden gerçekleştiğini dile getirmektedir.

Sosyal medyadan tanışsın ya da tanışmasın tüm evli çiftlerin sosyal medyayı evliliklerin başlangıcı için güvenilir bulması ile ilgili olarak, 23'ü kadın ve 27 'si erkek olmak üzere toplam 50 katılımcı sosyal medyayı güvensiz bulmaktayken, 2'si kadın ve 8'i erkek olmak üzere toplam 10 kat1lımcı devamında yüz yüze görüşme olması şartıyla sosyal medyayı evliliklerin başlangıcı için güvenilir bulmaktadır. Evli çiftlerin büyük oranda sosyal medyayı evlilik için güvenilir bir yer olarak görmedikleri açıkça görülmektedir.

Evli çiftlerin sosyal medyayı evliliklerin başlangıcı için güvensiz bulmalarının en temel sebebi ise, kişinin sosyal medyada kendisi gibi olmaması düşüncesidir. Diğer neden ise, her şeyin sanal olması ve birbirilerini yakından tanıyamama durumudur. Örneğin, kişinin sosyal medyada kendisi gibi olmamasıyla ilgili, 10 yıldır evli olan ve sosyal medyayı daha çok arkadaşları ile iletişim kurmak için kullanan bir kadın katılımcı şu ifadeleri kullanmıştır:

"Ben sosyal medyayı evliliklerin başlangıcı olarak güvenilir bulmuyorum. Çünkü insanlar sanal ortamda olduklarından çok farklı görünüyorlar. Burada istedikleri, arzuladıkları bir veya birden fazla kimliğe bürünebiliyorlar. Bundan dolayı sanal alem tamamen güvensiz bir ortam". (K29) 
Genel çerçevede ister sosyal medya üzerinden tanışsın isterse de evliliklerinde ya da tanışmalarında sosyal medyanın hiçbir rolü olmasın, katılımcıların çok büyük bir kısmı sosyal medyayı evlilik kurumu için, insanların birbirleri ile tanışmaları için güvenli bir mecra olarak görmemektedir.

\section{Evlenmeden Önce Eşin Sosyal Medya Hesapların Kontrol Etme}

Katılımcıların evlenmeden önce eşlerinin sosyal medya hesaplarını kontrol etme durumu ile ilgili olarak, 13'ü kadın ve 9'u erkek olmak üzere toplam 22 katılımcı kontrol ederken, 17'si kadın ve 21'i erkek olmak üzere toplam 38 katılımcı ise kontrol etmemiştir. Bu durumda, kadınların erkeklere oranla evlenmeden önce eşinin sosyal medya hesaplarını daha çok kontrol ettiklerini söylemek mümkündür. Kullanıcılar arasında 'stalk' ya da 'stalklamak' olarak tabir edilen bu süreçte, insanlar birisi ile tanışmadan önce ya da tanıştıktan sonra onun hakkında daha fazla bilgi edinmek amacıyla sosyal paylaşım ağlarında o kişi hakkında ayrıntılı bir araştırma yapabilmektedir. Çalışmaya dahil olan katılımcıların da önemli bir kısmı evlenmeden önce, eşlerinin bu sanal ortamdaki hesaplarını incelemiş ve onlar hakkında araştırma yapmışlardır.

Katılımcıların evlenmeden önce eşlerinin sosyal medya hesabını kontrol etmelerinin en temel sebebi, eşinin neler paylaştığını, neleri beğendiğini, kimlerle arkadaş olduğunu merak etmeleridir. Diğer bir neden ise eşi olacak kişi hakkında bilgi edinme arzusudur. Örneğin, merak etme düşüncesi ile ilgili, 7 yıldır evli olan ve sosyal medyayı daha çok gündemi takip etmek için kullanan lisans mezunu bir erkek katılımcı şu ifadeleri kullanmıştır:

"Toplum tarafindan hesabı nasıl görünüyor diye merak ettim. Bunu ona söyleme ihtiyacı duymadım. Girdim profilini inceledim. Acaba bana yakışmayacak bir paylaşımda bulunmuş mu, benim için sorun teşkil eden bir şeyler var mı ya da genel olarak hayata bakış açımı destekleyici paylaşımları söz konusu mu? Bunları merak ettim açıkçası". (E15)

Sosyal medya üzerinden eşiyle tanışan ve oradan görüşmeye devam eden ve $Y$ kuşağında yer alan söz konusu erkek katılımcı, evlenmeden önce eşinin sosyal medya profiline girip bazı şeyleri merak ettiği için kontrol etmek istemiştir. Burada kullanıcıların yapmış olduğu paylaşımların 
önemi ortaya çıkmaktadır. Görüldüğgü üzere yapılan bir paylaşım, gerçekleştirilen bir beğeni, yapılan bir yorum tanışma evresinde bir kişinin diğerinden uzaklaşmasına neden olabilmektedir. Ayrıca kişinin arkadaşlık kuracağ1 ya da evleneceği kişi ile benzer veya aynı düşünce yapısına sahip olması beklentisi de önemli bir unsur olmaktadır.

Bunun haricinde katılımcların evlenmeden önce eşlerinin sosyal medya hesapların kontrol etmemelerinin en temel sebebi ise, sosyal medyanın o dönemde yaygın olmaması ya da hiç olmamasıdır. Ayrıca kontrol etmemenin bir diğer nedeni de katılımcının eşine güvenme durumudur. Kişiyle birlikte yaşayarak onu tanıma isteği ise kontrol etmemenin bir diğer nedenidir.

\section{Sosyal Medya Hesap Şifrelerinin Paylaşılması}

Evli çiftlerin evlenmeden önce veya sonra eşleri ile sosyal paylaşım ağlarındaki hesaplarının şifrelerini paylaşma durumu incelendiğinde, $18^{\prime} \mathrm{i}$ kadın ve 19'u erkek olmak üzere toplam 37 kişinin şifresini eşiyle paylaştığ 1 tespit edilmiştir. Şifre paylaşma noktasında 5 katılımcı şifre paylaşım konusunun daha önce eşleri ile aralarında soruna yol açtığını söylerken, 55 katılımcı bu konunun aralarında hiçbir soruna yol açmadığını dile getirmektedir. Evli çiftlerin eşleriyle sosyal medya hesaplarının şifrelerini paylaşmalarındaki en temel sebep, çiftlerin aralarında gizlenecek bir şeyin olmamasıdır. Diğer neden ise sosyal medya hesabının ortak kullanılmasıdır. Aynı zamanda şifreyi akılda tutmanın zorluğu da çiftlerin en yoğun hissettiği üçüncü tür şifre paylaşma gerekçesidir.

Katılımcıların sosyal medya şifrelerini birbirleriyle paylaşmamalarının en temel sebebi ise, birbirlerine çok fazla güvenmeleridir. Paylaşmaya gerek duymama ve telefonda sosyal medyanın sürekli açık olması (şifresiz sosyal medyaya giriş yapabilme) da diğer şifre paylaşmama sebeplerindendir. Örneğin, evli çiftlerin birbiriyle şifre paylaşmaması ile ilgili, 25 yıldır evli olan ve sosyal medyayı daha çok arkadaşları ile iletişim kurmak için kullanan ilköğretim mezunu bir kadın katılımcı şu ifadeleri kullanmıştır:

"Birbirimiz ile şifre paylaşmıyoruz. Zaten ikimizin de telefonundan direkt şifre olmadan sosyal medya hesaplarına giriş yapabiliyoruz. Bir şey olsa eşim alır 
telefonumu direkt hesabıma şifresiz bir şekilde giriş yapabilir. Bu yüzden birbirimizle paylaşma gereksinimi hiç duymadık. Ayrıca birbirimize çok fazla güveniyoruz. Aramızda bu tür şeylerin lafı bile olmaz". (K27)

\section{Sosyal Medyanın Anlaşmazlıklara veya Boşanmalara Yol Açması}

Katılımcıların sosyal medya yüzünden anlaşmazlık yaşayan ya da boşanan çiftler tanıyıp tanımadıkları sorulduğunda, 13 katılımcı çevrelerinde sosyal medya yüzünden anlaşmazlık yaşayan çiftlerin olduğunu, 14 katılımcı sosyal medya yüzünden çevresinde boşanan çiftlerin olduğunu, 33 katılımcı ise, bu nedenle herhangi bir boşanmaya ya da anlaşmazlığa şahit olmadığını ifade etmiştir. Ayrıca 13 katılımcı boşanan kişilerin sosyal medya yüzünden boşandıklarını çevrelerine açıkça söylediklerini belirtmiştir. 6 yıldır evli olan ve sosyal medyayı daha çok arkadaşları ile iletişim kurmak için kullanan ilköğretim mezunu bir kadın katılımcı şu ifadeleri kullanmıştır:

“Çevremde sosyal medya yüzünden boşanan çiftler var. Tanıdığım kişinin eşi sosyal medyada geç saatlerde sürekli takılıyordu. Oradan başka sevgili buldu ve eşinden boşanarak onunla evlendi. Tanıdığım kişi de sosyal medya yüzünden ayrıldıklarını açık bir şekilde dile getiriyor". (K28)

\section{Sosyal Medyanın Evli Çiftler Arasında Soruna Yol Açması}

Sosyal medya kullanımının eşler arasında bir soruna neden olup olmadığ 1 incelendiğinde, 18 'i kadın ve 15'i erkek olmak üzere toplam 33 katılımc1 sosyal medyanın eşleriyle aralarında soruna neden olduğunu ifade etmiştir. Evli çiftler arasında sosyal medyanın yol açtığı en temel sorun, eşe/aileye az zaman ayırma ve kıskançlıktır. Bunlarla birlikte eşin sosyal medyada fazla zaman geçirmesi ve ilgisizlik eşler arasındaki diğer sorunlardır. Sosyal medyanın evliliklerde soruna yol açmasıyla ilgili olarak, 6 yıldır evli olan ve sosyal medyayı daha çok arkadaşları ile iletişim kurmak için kullanan ortaöğretim mezunu bir erkek katılımcı şu ifadeleri kullanmıştır:

"Sosyal medya aramizda sorunlara neden oluyor. Özellikle eşim bu konuda çok fazla sitemkâr. Sosyal medyada çok fazla zaman geçirdiğimi, ona ilgi göstermediğimi söylüyor. Hatta bazen bu sitemlerden bunalyorum. "Annene gitsene 
sen. Rahat rahat telefonla oynayayım" dediğim bile oluyor. Bazen ben de onu sosyal medyada fazla zaman geçirdiği için kıskanıyorum. "Kimle konuşuyorsun bu kadar?" diye soruyorum. Bazen telefonu elinden hiç düşürmediğinde, bu durum ben de güvensizliğe yol açabiliyor. 'Acabalar' geliyor aklıma. Endişe duyuyorum. Tüm bunlardan dolayı evliliğimizde bazen sosyal medya huzursuzluğa yol açabiliyor". (E28)

Verilere göre, sosyal medya evli çiftler arasında temelde eşe/aileye az zaman ayırma, ilgisizlik ve kıskançlık gibi sorunlara yol açmaktadır. Türkiye'de günlük ortalama internet kullanım süresinin 7 saat 15 dakika ve sosyal medya kullanım süresinin 2 saat 46 dakika olduğu (Kemp, 2019) dikkate alındığında, evli çiftler arasında özellikle evde çevrimiçi ortamda fazla zaman geçirme kaynaklı sorunların ortaya çıkması kaçınılmaz olmaktadır. Sosyal medyada fazla zaman geçirmenin, çiftler arasında endişeye neden olduğunu da söylemek mümkündür.

\section{Karşı Cins ile Sosyal Medya Üzerinden Gerçekleşen Etkileşimin Evliliğe Etkisi}

Sosyal medyada eşlerinin karşı cins ile kurduğu etkileşimin evliliklerini etkileyip etkilemesi incelendiğinde, 12 'si kadın ve 16'sı erkek olmak üzere toplam 28 katılımcı karşı cins ile eşin etkileşiminin evliliklerini etkileyeceklerini söylemektedir. Verilere göre, erkekler kadınlara oranla daha fazla karşı cins ile kurulan etkileşimden rahatsız olmaktadır. Bu noktada, evli çiftler arasında karşı cins ile kurulan etkileşimin yol açtı̆̆ı en temel sorun, bunun eşler arasında huzursuzluğa neden olmasıdır. Etkileşimden duyulan rahatsızlığın bir diğer nedeni ise kıskançlıktır. Ayrıca eşin tanımadığı bir karşı cins ile etkileşim kurmasının evliliği olumsuz etkilemesi de bir diğer sorun olarak görülmektedir. Katılımcılardan 10 yıldır evli olan ve sosyal medyayı daha çok haber ve bilgi için kullanan lisansüstü eğitim düzeyine sahip bir erkek katılımcı şu ifadeleri kullanmıştır:

"Sosyal medyada bir erkek ile eşimin kurduğu bir etkileşimin evliliğimiz etkilemesi, karşısındaki kişiye göre değişir. Kişi benim veya eşimin yakın akrabası ise, sorun olmaz. Fakat karşı cins benim tanımadığım veya eşimin çocukluk ya da okul arkadaşıysa ve bu süreklilik arz ediyorsa evliliğimizi etkiler. Sorun olur benim için." (E29) 
Sosyal medyada evli çiftlerin eşlerine yönelik karşı cinsten gelen bir etkileşimin evliliklerini etkilememesinin en temel sebebi ise, birbirlerine olan güvendir. Verilere göre kadınlar erkeklere göre karşı cins etkileşimi konusunda eşlerine daha fazla güvenmektedir. Bu konuda, 5 yıldır evli olan ve sosyal medyayı daha çok eğlence için kullanan ön lisans eğitim düzeyine sahip bir kadın katılımcı şu ifadeleri kullanmıştır:

"Sosyal medyada karşı cins ile eşimin kurduğu bir etkileşim karşı cins durumu farkh bir yöne çekmediği sürece evliliğimiz etkilenmez. Biz birbirimize sonuna kadar inanır ve güveniriz. Eşimin evliliğimizi etkileyecek yanlış bir şey yapmayacağına çok fazla inanıyorum. Bu tür şeyler bizim evliliğimizde sorun oluşturmaz. Çünkü eşime gözüm kapalı güvenirim. Ama dediğim gibi karşı taraf yeter ki bu etkileşimi farkl, sorunlu bir yöne çekmesin". (K14)

\section{Sosyal Medya Kullanımı Konusunda Çiftlerin Kurallar Koyması}

Sosyal medya konusunda, eşlerin birbirlerine birtakım kurallar koyma gerekliliği noktasında, 42 katılımcı kurallar konulması gerektiğini belirtirken, $10^{\prime}$ u kadın ve 8'i erkek olmak üzere toplam 18 katılımcı ise, kurallara gerek olmadığını ifade etmektedir. Verilere göre, erkekler kadınlara oranla biraz daha fazla evli çiftlerin sosyal medya kullanımında birtakım kurallar olması gerekliliğini vurgulamaktadır. Bu konuda verilere göre, sosyal medyada evli çiftlerin birbirlerine koymaları gereken en temel kural, çiftler arasında sosyal medya kullanımında belirli bir zaman kısıtlamasının olmasıdır. Ayrıca sosyal medyada çok fazla zaman geçirilmemesi gerekliliği de diğer bir kural olarak değerlendirilmektedir. Bunun yanı sıra, eşin sevmediği ya da onaylamadığ kişilerle sosyal medyada iletişim kurmama da sık belirtilen bir başka kuraldır. 4 yıldır evli olan ve sosyal medyayı daha çok arkadaşları ile iletişim kurmak için kullanan, lisans eğitim düzeyine sahip bir kadın katılımcı şu ifadeleri kullanmıştır:

"Kesinlikle evli çiftler sosyal medya kullanımı konusunda birbirlerine kurallar koymalıdır. Kişiler birbirilerine zaman ayırmal ve sürekli çiftler sosyal medyada olmamalıdır. Sosyal medya ortaya çıktığından beri insanlar yüz yüze sohbet edemiyor. Ben sadece boş kaldığımda sosyal medyaya bakıyorum. Ama eşim öyle değil. Evde bir iş söylesem ve o anda sosyal medyada olsa o işi yapmıyor, hala orada takılmaya devam ediyor. İşten eve geldiğinde, çiftler birbirlerine daha çok zaman ayırmalı. Sürekli sosyal medyada olunmamall. Akşamları bir yarım saatte olsa 
sosyal medyaya göz atılabilir. Ondan sonra iki tarafta telefonu elinden birakmaln ve acil bir durum olmadıkça bir daha sosyal medyaya bakılmamal. Yani, eşler arasında sosyal medya kullanım konusunda belirli bir saat dilimi olmalıdı"." (K20)

Katılımcıların, sosyal medya kullanımı konusunda çiftlerin birbirilerine kurallar koymasına gerek duymamalarının en temel sebebi ise, çiftlerin birbirlerine karşı duydukları güvendir. Evliliğin kurallar üzerine kurulmaması ve bireylerin özgür olması anlayışı da diğer sebepleri teşkil etmektedir.

\section{Sosyal Medyanın Evliliklerde Tehdit Olması}

Evli çiftlerin sosyal medyayı bir tehdit olarak görüp görmedikleri incelendiğinde, 14'ü kadın ve 16'sı erkek olmak üzere toplam 30 katılımcının sosyal medyayı evliliklerde tehdit olarak gördügü ortaya çıkmaktadır. Verilere göre, sosyal medyanın evlilikler için bir tehdit oluşturup oluşturmadığı konusunda katılımcılar arasında kesin bir ayrım bulunmamaktadır. Yani katılımcıların yarısı tehdit olarak görürken diğer yarısı tehdit olarak görmemektedir. Sosyal medyayı evlilikler için bir tehdit olarak gören katılımcıların en temel gerekçesi, eşlerin sosyal medyada çok fazla zaman geçirmesidir. Sosyal medyanın aldatmaya yol açması ve huzursuzluğa neden olması ise, diğer tehdit gerekçeleridir. Bu konuda, 6 yıldır evli olan ve sosyal medyayı daha çok arkadaşları ile iletişim kurmak için kullanan, ortaöğretim eğitim düzeyine sahip bir erkek katılımcı şu ifadeleri kullanmıştır:

"Bence sosyal medya evlilikler için bir tehdit oluşturuyor. Buralarda evli çiftler, erkek ya da kadın olsun hiç fark etmez, karşı cins ile arkadaşlık kurup bunu ilerletebilir. Hatta bu eşi aldatmaya kadar gidebiliyor. Çünkü insanlar sanal alemde kendilerini daha farkl görüyorlar ve günlük hayata göre daha rahat hissediyorlar. "Aman kim bilecek ki" diye düşünüp çok yanlış davranışlar içine girebiliyorlar. Bu durum ileride evlilikleri de doğrudan etkiyebilmektedir". (E28)

Katılımcıların, sosyal medyayı evliliklerde bir tehdit olarak görmemelerinin en temel sebebi ise, kişinin kendini bilmesidir. Ayrıca doğru kullanıldığı sürece tehdit olmaz anlayışı ise diğer sebeptir. Sosyal medyayı evlilikler için bir tehdit olarak görmeyen katılımcılar kendilerini; "eğer kişi kendini bilir ve doğru bir şekilde sosyal medyayı kullanırsa bir tehdit 
oluşmaz. Ancak bu durum gerçekleşmezse yani tersi olursa, sosyal medya evlilikler için tehdit olmaya başlar" şeklinde ifade etmektedirler.

\section{Sonuç}

Farklı demografik özelliklere ve farklı sosyal paylaşım ağı kullanım örüntülerine sahip olan katılımcılarla yapılan araştırma neticesinde, katılımc1ların evlilikleri ile sosyal medya kullanımları arasındaki ilişki tespit edilmiştir. Bununla birlikte katılımcıların, evlilikte yaşanan sorunlarda sosyal medyanın etkisinin ne olduğu, sosyal medyanın evlilik sürecinde kullanılabilecek güvenilir bir ortam olup olmadığı ve boşanmalarda sosyal medyanın etkisinin bulunup bulunmadığı gibi konularda görüşleri de çalışma kapsamında elde edilmiştir.

Araştırmada, katılımcların büyük bir kısmı evli olduklarını sosyal medya hesaplarında belirtmektedirler. Kimeto (2016)' dan farklı olarak çalışmada, erkeklerin kadınlara oranla daha fazla ilişki durumlarını sosyal medya hesaplarına yazmakta oldukları ortaya konulmuştur. Çiftlerin ilişki durumlarını sosyal medya hesaplarında yazma gerekçeleri ise, diğer kullanıcılara gösterme ve rahatsız edilmeme isteğidir. Özellikle karşı cins tarafından rahatsız edilme, evliliklerde sorunlara yol açabilmektedir. Bireyler sosyal medya hesaplarında ilişki durumu bölümüne evli oldukların yazarak bu konuda kendilerini koruma altına almaktadırlar. Bunun yanı sıra, çiftlerin çoğunluğu sosyal medyada aileleri ile ilgili içerikler paylaşmaktadırlar. Bu paylaşımları yapmalarının en temel sebebi de diğer kullanıcılara bunları gösterme isteğidir. Sosyal medyanın ortaya çıkıp gelişim göstermesiyle birlikte artık insanlar üzüntü, sevinç, eleştiri, kızgınlık gibi duygularını rahat bir şekilde takipçileri ile paylaşabilmektedir. Araştırmada katılımclar özellikle aile mutluluklarını sergileyebilecekleri bir alan olarak sosyal medyayı görmekte ve diğer kullanıcılarla bu tür içerikleri paylaşmaktan hoşlanmaktadırlar. Diğer taraftan, aile ile ilgili sosyal medyada paylaşım yapmayan katılımcılar ise, özel hayatın gizliliğini ve mahremiyetin kutsallığını düşünmektedir. Çünkü sosyal paylaşım ağları, insanların kimlik bilgileri, kişisel bilgileri ve aile bilgileri gibi en mahrem bilgileri veri tabanlarına kaydetmektedir. Kaydedilen bu bilgiler özel şirketlere (reklam aracılığıyla gelir elde etmek için) ve gücü elinde bulundu- 
ranlara (kontrol ve manipülasyon için) para karşılığ 1 verilmektedir. Bunun haricinde bu en mahrem bilgiler, fotoğraflar ve videolar diğer kullanıcılar tarafından da görülebilmektedir. Bu da bireyin özel alanının zarar görmesine, alenileşmesine ve bir seyirlik nesne biçimine dönüşmesine neden olmaktadir.

Eroğlu (2012), farklı öğrenim seviyelerindeki bireylerin sosyal ağlarda tanıştıkları kişilerle evlenmeye onay vermediklerini ortaya koymaktadır. Buradan hareketle evlilik kurumunun önemini koruduğu, yapılan evlilikte yüz yüze iletişimin ve güvenin bireyler tarafından önemli bulunduğunu söylemek mümkündür. Söz konusu bu araştırmada ortaya çıkan bulgular, Eroğlu (2012)'nu destekler niteliktedir. Sosyal medya üzerinden tanışanlar da dahil olmak üzere katılımcıların büyük bir çoğunluğu, sosyal medyayı evliliklerin başlangıcı için onaylamamaktadır. Bunun en temel sebebi de sosyal medyada kişinin kendisi gibi olmayıp farklı kimliklere ve karakterlere bürünebilmesidir. Sosyal medya ortamında kullanıc1ların doğal bir şekilde davranmadıkları, Elvin Goffman'ın tabiri ile birtakım 'maskeler' taktıkları söylenebilmektedir. Bu maskeler yoluyla karşısındaki kişiyi çok rahat bir şekilde kandırabilen insanlar, kendilerini yapay bir 'sahnede' sergilemektedir.

Bunun haricinde evliliklerde kadın ya da erkeğin sosyal medyada karşı cinsin fotoğrafını beğenmesi ya da paylaşımlara yorum yapması, onların ilişkilerinde kıskançlığın meydana gelmesine neden olabilmekte ve ilişkiyi çıkmaza sokabilmektedir. Bunun gibi birçok nedenden ötürü hem kadın hem de erkek kullanıcılar, sosyal medya platformunu eşlerini kontrol etmek, gözetlemek ve izlemek amacıyla kullanmaktadır (Wilkerson, 2017). Özelikle bu gözetleme ve kontrol etme durumu ilk tanışma aşamalarında daha sık görülmektedir. Araştırmada katılımcıların bir kısmı, özellikle de kadınlar, evlenmeden önce eşlerinin sosyal medya hesaplarında neler paylaştığını, neleri beğendiğini, kimlerle arkadaş olduğunu merak ettikleri için kontrol etmektedir. Merakın yanı sıra eşler ile ilgili birtakım bilgileri elde etmek için de sosyal medya profilleri eşler tarafından incelenmektedir.

Bu merak unsuru evlendikten sonra da devam edebilmektedir. Öyle ki sosyal paylaşım ağlarında hesapları olan çiftler, şifrelerini saklamalarını gerektirecek bir şey olmadığ i için ve birbirlerinin hesaplarını merak ettikleri için birbirleriyle rahatça şifrelerini paylaşabilmektedir (Williams, 
2012, s.61). Çalışmada yapilan araştırmada da aynı sonuca ulaşılmıştır. Evli çiftlerin eşleriyle sosyal medya hesaplarının şifrelerini paylaşmalarındaki en temel sebep, çiftlerin aralarında gizlenecek bir şeyin olmaması olarak ortaya çıkmıştır. Öte yandan, Williams (2012, s.28) evli çiftlerin büyük bir çoğunluğunun birebirleriyle şifrelerini paylaşmadıklarını ortaya koymuştur. Yapılan araştırmada ise, tam ters, bir sonuca ulaşılmıştır. Elde edilen verilere göre katılımcıların birçoğu sosyal medya şifrelerini birbiriyle paylaşmaktadır. Ayrıca çiftler arasında şifre paylaşma konusunda çok az sorun ortaya çıkmıştır. Katılımcıların şifrelerini birbiriyle paylaşmamalarının en temel gerekçesi ise, güven duyma unsurudur.

Farklı amaçlarla farklı şekillerde ve sürelerde kullanılan bu sanal ortam, evli bireyler arasında sorunların doğmasına hatta kimi zaman evliliklerin sonlanmasına dahi neden olabilmektedir. Eşler arasında sosyal medyanın etkisi boşanma yüzdesini yükseltici yönde etki etmektedir. Eşlerin sosyal medya kaynaklı birbirlerine ayrılan zamanın kısalması, sosyal medyada yapılan paylaşım, beğeni, etkileşim vb. durumlar zaman zaman tartışmalara sebep olmakta hatta bu tartışmaların sonucunda boşanmaya kadar gidilebilmektedir (Güleç, 2018, s.118). Çalışmada katılımcıların bir kısmı çevrelerinde sosyal medya yüzünden anlaşmazlık yaşayan hatta boşanan kişilerin olduğunu söylemektedirler. Özellikle boşanan çiftler de sosyal medya yüzünden boşandıklarını açıç̧a itiraf etmektedir. Bu tür boşanmalarda aldatma faktörü öne çıkmaktadır. Sosyal medya ortamında sevgi açlı̆̆ını ve duygusal boşluğunu doyurma gayreti içerisine giren bireyler, sosyal medyayı aşırı ve amacı dışında kullanmaya yönelebilmekte ve aldatma davranışında bulunabilmektedir. Özellikle genç yetişkinler tarafından sosyal medyanın aşırı ve amaç dışı kullanımı arttıkça aldatmaya yönelik tutumların da artacağı aşikâr olmaktadır (Dursun ve Özkan, 2019, s.482). Carter (2016, s.38)'ın belirttiği gibi, sosyal medya platformlarında çevrimiçi etkileşimin birtakım kuralları, başka bir deyişle 'kırmızı ışıkları' yoktur. Metin yoluyla erkekler ve kadınlar arasındaki etkileşimlerin hızlı bir şekilde gelişmesi mümkündür. Fiziksel bir durum söz konusu olmadığı için de en derin istekler ve düşünceler ortaya çıkabilmektedir.

Yapılan psikoloji temelli bazı araştırmalara göre, sosyal medya aynı evde yaşayan aile bireylerinin birbirleriyle olan iletişimlerinin gerilemesine, depresyona, sosyal hayattaki çevrelerinin daralmasına ve yalnızlık 
duygularının artmasına neden olmaktadır (Castells, 2005, s.477). Araştırmada, katılımcıların yarıdan fazlası sosyal medya kullanımının evliliklerinde birtakım sorunlara neden olduğunu söylemektedir. Eşe/aileye az zaman ayırma, kıskançlık ve ilgisizlik en dikkat çekici sorunlar olarak öne çıkmaktadır. Bu durum Castells (2005)'in de belirttiği gibi çiftler arasında iletişimin gerilmesine ve sorunların ortaya çıkmasına yol açabilmektedir.

Çevrimiçi dünya ilişkiyi etkileyebilir, sahiplenme ve kıskançlık duygularını yoğunlaştırabilir. Sosyal medyada halka açı bir ilişki sergileyen birey alt metinde ilişkisinde ne denli ciddi olduğunun mesajını vermektedir. Sosyal ağda yapılan eski ve yeni paylaşımlar da ilişkinin gidişatını etkileyebilmektedir. Çiftler kıskançlık yüzünden birbirlerinden, istenmeyen fotoğrafları ya da kişileri (eski erkek arkadaş, sevilmeyen bir arkadaş vb.) silmelerini isteyebilmektedir. Aynı şekilde bir paylaşıma yapılan yorum ya da beğeni de ilişkinin gidişatını belirleyebilmekte ve soruna yol açabilmektedir (Mod, 2010, s.73-74). Literatürde çoğunlukla, karşı cinsle sosyal medya aracılığıyla etkileşim kurarken neyin uygun veya neyin uygunsuz davranışlar olabileceği ile ilgili eşler arasında genel bir fikir birliği kurulmuş değildir (Carter, 2016, s.38; Wilson vd., 2011, s.80-81). Araştırmada ise, karşı cins ile sosyal medya üzerinden gerçekleşen etkileşimin evliliği etkileyip etkilemeyeceği analiz edildiğinde, katılımcıların hemen hemen yarısı evliliklerini etkileyebileceğini söylemektedirler. Bu durumun özellikle çiftler arasında huzursuzluğa ve kıskançlığa yol açabileceği öne sürülmektedir. Diğer taraftan, katılımcıların bir kısmı da karşı cins ile sosyal medya üzerinden gerçekleşen etkileşimin birbirlerine olan sonsuz güvenden dolayı evliliklerini etkilenmeyeceğini vurgulamaktadırlar.

Evliliklerde özellikle sözlü birtakım kurallar mevcuttur. Bunlar yaşanılan kültürün ve toplumun içinden bizzat çıkış kurallardır. Bu kurallar evlilik kurumunun sağlıklı bir şekilde işlemesinde ve sürdürülmesinde önemli etkilere sahiptir. Bu noktada Williams (2012, s.17)'a göre, evliliklerde sosyal medya kullanım kurallarını da belirlemek eşler arasındaki çatışmayı önleyici bir tedbir olarak değerlendirilebilmektedir. Söz konusu bu çalışmada katılımcıların çoğunluğu sosyal medya kullanımı ile ilgili eşler arasında kurallar olmasının gerekliliğinden bahsetmektedir. Özellikle konulması gereken en önemli kural, eşlerin sosyal medyada geçirdikleri zaman ile ilgili kısıtlamadır. Katılımcılar eşlerinin sosyal medyada çok 
fazla zaman geçirdiklerinden ve bu yüzden kendilerine ilgi göstermediklerinden yakınmaktadırlar. Şad vd. (2016, s.166)'ne göre, sosyal medya kullanımı aile olarak birlikte geçirilen zamanın kalitesini ve süresini tehdit ediyorsa, eşler arasında iletişimin zayıflaması gibi sorunlara yol açabilmektedir.

Kurallar konulsa da konulmasa da birçok kullanıcı için sosyal medya evlilik veya ilişki için potansiyel bir tehlike olarak görülmektedir. McDaniel vd. (2017, s.88-89) de sosyal paylaşım ağlarını, mevcut romantik ilişkilere karşı potansiyel bir tehdit olarak değerlendirmektedir. Çiftlerin sosyal ağlar üzerinden, gizli şekilde geçmişteki sevgili ve arkadaşları ile yeniden arkadaşlık kurma hatta flört etme gibi evlilikler için tehdit oluşturacak birtakım önemli durumlar meydana gelebilmektedir. Bu minvalde araştırmada da katılımcıların yarısı sosyal medyayı evlilikler için bir tehdit olarak görürken, diğer yarısı kişinin kendini bilmesi ve doğru bir şekilde sosyal medyayı kullanması koşuluyla tehdit olmayacağını belirtmektedir. Sosyal medyanın doğrudan evlilikler için bir tehdit olmasının temel sebepleri ise, eşlerin sosyal medyada fazla zaman geçirmesi ve evlilikte aldatma ve huzursuzlukların ortaya çıkmasıdır.

Araştırma, Türkiye genelinde rastgele seçilen evli çiftler ile sınırland1rılmıştır. Bir başka çalışmada, coğrafi bölgelere ayrılarak bir araştırma gerçekleştirilebilir. Bu sayede, farklı bölge ve kültürler arasındaki evli çiftlerin sosyal medya kullanım süreçleri incelenebilir. Diğer taraftan, araştırma sadece evli çiftler üzerinden gerçekleştirilmiştir. Gelecekteki araştırmacılar, boşanan çiftler üzerinde sosyal medyanın boşanmaktaki rolü ile ilgili bir çalışma yapabilirler. Son olarak, araştırma verileri sadece yarı yapılandırılmış görüşme tekniği ile toplanan verilerle sınırlıdır. Gelecek çalı̧̧malarda, evli çiftlerin sosyal medya kullanımları üzerinde örneklemi evrene genelleyip daha genel bulgular elde etmek adına anket tekniği kullanılarak bir araştırma yapılabilir. 


\title{
EXTENDED ABSTRACT
}

\section{The Impact of The Usage of Turkey's Married Individuals' Social Media Usage on Their Marriage: A Qualitative Research}

\author{
* \\ Sefer Kalaman - Fatih Çelik \\ Bozok University, Trabzon University
}

Research about social media in the marriage of married individuals in Turkey aims to reveal to what extent it is effective. Communication, technology and family(domestic) relations have evolved to different dimensions in parallel with the change of age. Without any doubt, social media has become an important factor in the formation of the family or in the emergence of domestic problems. In many academic studies, it has been revealed that social media has an important role in shaping domestic relations, debates and even divorces. Starting from this point, it is important to analyze that how social media use among married individuals in Turkey effect their marriage and play a role in their marriage, and how much impact social media usage has in the domestic problems. There are studies on domestic violence and divorce in Turkey. However, the relationship between social media and the construction of marriage, domestic violence, and divorce hasn't been examined enough. Therefore, it is thought that this study will contribute to the literature since it will examine the relationship between marriage and social media in depth.

In the study, semi-structured interview technique, which is one of the qualitative research methods, was used to obtain the data. Interview was carried out with the $X$ and $Y$ generations, using social networking and married individuals living in different provinces of Turkey. During the meeting, open-ended questions were asked to the participants and they were asked to provide more detailed information about the subject. The universe of the study consists of married individuals in Turkey. 60 married individuals residing in different provinces of Turkey were selected as 
samples. The interviews were conducted between March 2019 and April 2019. MAXQDA analysis program was used for data analysis.

As a result of the research conducted with the participants who have different demographic characteristics and patterns of use of social networking, the relationship between the marriages of the participants and their use of social media was detected. In addition, the opinions of the participants about the impact of social media on marital problems, whether the social media is a reliable environment that can be used in the marriage process and whether the social media has an effect on divorces were also obtained within the context of the study.

In the research, most of the participants stated in their social media accounts that they are married. The reasons for couples to write their relationship status in their social media accounts are the desire to show to other users and not to be disturbed. The majority of participants, including those who meet through social media, do not approve of social media for the beginning of marriage. The main reason for this is that people in social media can take on different identities and characters. In addition to this, the fact that women or men like the photo of the opposite sex on social media or comment on the posts can lead to jealousy in their relations and lead to a deadlock in marriage. In the research, some of the participants, especially women, check what their husbands share in their social media accounts, what they like and who they are friends with before they get married. Beside curiosity, social media profiles are examined by couples to obtain information about their spouses. This curiosity can continue after marriage. Married couples can share their passwords with each other easily because there is nothing to keep their passwords secret and they are curious about each other's accounts. The main reason why married couples share the passwords of their social media accounts easily with their spouses is that the couples have nothing to hide between them.

This virtual environment, which is used in different ways, for different purposes and for different times, can cause problems between married individuals and sometimes even end marriages. In the study, some of the participants stated that there were people who had disagreements due to social media or even divorced. Especially divorced couples openly admit that they divorced because of social media. In these divorces, the deception(deceiving) factor steps forward. Apart from divorces, social media 
can cause other problems between couples. In fact, in the research, more than half of the participants say that the use of social media causes some problems in their marriage. Sparing time for the spouse / family, jealousy and apathy are the most remarkable problems.

From this point of view, the majority of the participants in the study mentioned that there should be rules between spouses regarding social media use. Especially the most important rule to be set is the restriction on the time couples spend on social media. But for many users, whether or not rules are set, social media is seen as a potential danger for marriage or relationship. In this study, while half of the participants perceive social media as a threat to marriages, the other half states that they will not be threatened provided that the person knows himself and uses social media correctly. The main reasons why social media is a threat to direct marriages is that couples spend too much time on social media, and that deception and problems occur.

Research was limited to married couples randomly selected throughout Turkey. In another study, a research can be carried out by dividing the country into geographical regions. In this way, the social media usage processes of married couples between different regions and cultures can be examined. On the other hand, the research was conducted only on married couples. Researchers in future may study the role of social media in divorce on divorced couples. Finally, the research data is limited to the data collected by the semi-structured interview technique. In future studies, a survey can be conducted on the use of social media by married couples to generalize the sample to the universe and to obtain more general findings.

\section{Kaynakça / References}

Acılığlu, İ. (2015). İş'te Y kuşağı. Ankara: Elma Yayınevi.

Alikılıç, Ö., Alikılıç, İ. ve Özer, A. (2019). Dijital romantizm: Y kuşağının romantik ilişkilerinde sosyal medyanın rolü üzerine bir araştırma. Erciyes İletişim Dergisi Uluslararası Dijital Çağda İletişim Sempozyumu Özel Sayısı, 1, 57-80.

Baycan, P. (2017). Y kuşağının satın alma davranışları üzerinde sosyal medyanın etkisi. Dış Ticaret Enstitüsü, Working Paper Series, İstanbul. 
Broadbridge, A. M., Maxwell, G. A. ve Ogden, S. M. (2007). Experiences perceptions and expectations of retail employement for generation Y. Career Development International, 12(6), 1-39.

Can, F. ve Hovardaoğlu S. (2015). Romantik ilişkilerde sosyal ağ etkileri. Nesne, 3(5), 43-65.

Carter, A. Z. (2016). Married and previously married men and women's perceptions of communication on facebook with the opposite sex: How communicating through Facebook can be damaging to marriages. Journal of Divorce \& Remarriage, 57(1), 36-55.

Castells, M. (2005). A ̆̆ toplumunun yükselişilenformasyon çă̆l: Ekonomi, toplum ve kültür. (E. Kılıç, Çev.). İstanbul: Bilgi Üniversitesi Yayınları.

Dursun, A. ve Özkan, M. S. (2019). Genç yetişkinlerin aldatmaya yönelik niyetleri üzerinde aldatmaya yönelik tutum ve sosyal medya kullanımının etkisi. Kastamonu Eğitim Dergisi, 27(2), 475-484.

Eroğlu, S. E. (2012). Sanal topluluklardaki sosyal ağlarda sosyalleşme ve güven sorunsalı Ereğli örneğgi. Yayınlanmamış Yüksek Lisans Tezi, Selçuk Üniversitesi, Konya.

Fox, J. ve Warber, K. M. (2014). Social networking sites in romantic relationships: Attachment, uncertainty, and partner surveillance on Facebook. Cyberpsychology, Behavior, and Social Networking, 17(1), 3-8.

Güleç, V. (2018). Aile ilişkilerinin sosyal medyayla birlikte çöküşü. Yeni Medya Elektronik Dergisi, 2(1), 105-120.

Güz, N. ve Yeğen, C. (2017). Ölü Canlar'dan Instagram'a kimlik ve statü sahibi olmanın Allomorfizmi üzerine. İletişim Kuram ve Araştırma Dergisi, 45, 103-123.

Kemp, S. (2019, Ocak 30). Digital 2019, Global Internet use accelerates. 25 Haziran 2019 tarihinde https://wearesocial.com/blog/2019/01/digital2019-global-internet-use-accelerates adresinden erişildi.

Kılıç, T. Ve Gündoğdu, G. (2017). Yeni iletişim teknolojilerinin sosyal hayata etkileri: internet evlilik siteleri. 1. Uluslararası İletişimde Yeni Yönelimler Konferansi, İstanbul.

Kimeto, J. (2016). The effect of social media on marital success: A case of lang'ata constituency, Nairobi County, Kenya. Unpublished Master's Thesis. Pan Africa Christian University, Nairobi.

Marshall, T. C., Bejanyan, K., Castro, G. D. ve Lee, R. A. (2013). Attachment styles as predictors of Facebook-related jealousy and surveillance in romantic relationships. Personal Relationships, 20, 1-22. 
McDaniel, T. B., Drouin, M. ve Cravens, J. D. (2017). Do you have anything to hide? Infidelity-related behaviors on social media sites and marital satisfaction. Computers in Human Behavior, 66, 88-95.

Mod, G. B. B. A. (2010). Reading romance: The impact Facebook rituals can have on a romantic relationship. Journal of Comparative Research in Anthropology and Sociology, 1(2), 61-77.

Okur, H. D. ve Özkul, M. (2015). Modern iletişimin arayüzü: Sanal iletişim sosyal paylaşım sitelerinin toplumsal ilişki kurma biçimlerine etkisi (Facebook örneği). Süleyman Demirel Üniversitesi Sosyal Bilimler Enstitüsü Dergisi, 21, 213-246.

Özpolat, V. (2014). Postmodern bir sosyalleşme mecrası olarak sosyal medya ve gençlik. Gençlik ve Kültürel Mirasımız Uluslararası Kongre, Samsun.

Prensky, M. (2001). Digital natives digital ımmigrants. On the Horizon, 9(5), 16.

Subaşı, E. ve Urtekin, M. C. (2014). Sosyal değişmenin genç aileler üzerinde boşanmaya etkisi. Gençlik ve Kültürel Mirasımız Uluslararası Kongre, Samsun.

Şad, N. S., Konca, S. A., Özer, N. ve Acar, F. (2016). Parental envolvement: A phenomenological research on electronic parental involvement, International Journal of Pedagogies and Learning, 11(2), 163-186.

Tokunaga, R. S. (2011). Social networking site or social surveillance site? Understanding the use of interpersonal electronic surveillance in romantic relationships. Computers in Human Behavior, 27, 705-713.

TÜIKK-Türkiye İstatistik Kurumu (2018, Ağustos 8). Hanehalkı bilişim teknolojileri kullanım araştırması. 7 Temmuz 2019 tarihinde http://www.tuik.gov.tr/PreTablo.do?alt_id=1028\# adresinden erişildi.

UHIM-Uluslararası Hak İhlalleri İzleme Merkezi (2011, Nisan 1). Sosyal paylaşım siteleri soruşturması. 26 Mayıs 2019 tarihinde https://uhim.org/Uploads/GenelDosya/sosyal-paylasim-siteleri-sorusturmasi-2723-d.pdf adresinden erişildi.

Uslu, İ. (2012). Sosyal medya oyunlarında gerçeklik olgusunun yön değiştirmesi: Smeet oyunu örneği. Gümüşhane Üniversitesi Illetişim Fakültesi Dergisi, 3, 55-88. 
Wilkerson, K. T. (2017). Social networking sites and romantic relationships: Effects on development, maintenance and dissolution of relationships. Inquiries Journal, 9(3). 30 Mayıs 2019 tarihinde http://www.inquiriesjournal.com/a?id=1576 adresinden erişildi.

Williams, L. M. (2012). Facebook ruined my marriage: Digital intimacy interference on social networking sites. Unpublished Master's Thesis. Media Studies at Syracuse University, Syracuse.

Wilson, K., Mattingly, B. A., Clark, E. M., Weidler, D. J., ve Bequette, A. W. (2011). The gray area: Exploring attitudes toward infidelity and the development of the perceptions of dating infidelity scale. The Journal of Social Psychology, 151(1), 63-86.

Yıldız, A. K. (2012). Sosyal paylaşım sitelerinin dijital yerlilerin bilgi edinme ve mahremiyet anlayışına etkisi. Bilgi Dünyası, 13(2), 529-542.

\section{Kaynakça Bilgisi / Citation Information}

Kalaman, S. ve Çelik, F. (2019). Türkiye'deki evli bireylerin sosyal medya kullanımlarının evlilikleri üzerine etkisi: Nitel bir araştırma. OPUS-Uluslararası Toplum Araştırmaları Dergisi, 13(19), 424-453. DOI: $10.26466 /$ opus.589684 